\title{
Richness of Dendrocephalus (Branchiopoda, Anostraca) in Brazil with the description of two new species
}

\author{
Nicolas RABET ${ }^{1, *}$, Sébastien LACAU ${ }^{2} \&$ Reinaldo L. BOZELLI ${ }^{3}$ \\ ${ }^{1}$ Sorbonne Université, UPMC Univ Paris 06, CNRS, Unité Biologie des organismes et écosystèmes \\ aquatiques (BOREA, UMR 7208), Muséum national d'Histoire naturelle, \\ Université Pierre et Marie Curie, Université de Caen Normandie, Université des Antilles, \\ CNRS, IRD, CP26 75231, 43 rue Cuvier, Paris Cedex 05, France. \\ ${ }^{1,2}$ Universidade Estadual do Sudoeste da Bahia, Laboratório de Biossistemática Animal, BR 415, \\ km 03.45700-000 Itapetinga, Bahia, Brazil. \\ ${ }^{3}$ Universidade Federal do Rio de Janeiro, Laboratório de Limnologia, Departamento de Ecologia, \\ Instituto de Biologia, CCS, Av. Carlos Chagas Filho, 373, CEP 21941-590 Rio de Janeiro, RJ, Brazil. \\ *Corresponding author: nicolas.rabet@sorbonne-universite.fr \\ 2Email:slacau@uesb.edu.br \\ 32Email: bozelli@biologia.ufrj.br \\ ${ }^{1}$ urn:1sid:zoobank.org:author:287D7573-79F1-432C-84E1-CDFED2999AB2
${ }^{2}$ urn:lsid:zoobank.org:author:ABA3BECA-A630-4608-993B-00A741B21F6A
${ }^{3}$ urn:Isid:zoobank.org:author:F4DE0445-C4CF-4A79-85BC-87C0DF94427B
}

\begin{abstract}
We present an overview of the morphological diversity and geographical distribution of the anostracan genus Dendrocephalus Daday, 1908, and describe two new species: D. aranai sp. nov. from Jequitinhonha in the state of Minas Gerais and D. xikrini sp. nov. from the Carajás Mountains (Serra dos Carajás) in the state of Pará. These species have important similarities to D. goiasensis Rabet \& Thiéry, 1996 and D. thieryi Rabet, 2006, respectively, but differ from them and each other through a combination of characters that are essentially unique to the endopods, and frontal appendage branch 2A and branch 2D. We also partly redescribe D. carajaensis Rogers, Gomes \& Vieira, 2012, which shows a particular intra-populational variability in branch 2A and 2D III of the frontal appendage, a type of polymorphism that was also recently observed in D. orientalis Rabet \& Thiéry, 1996 and which must now be taken into account in taxonomy. In terms of the distribution of species of Dendrocephalus in Brazil, we suggest that several other species are probably present in the Amazonian, Cerrado and Pantanal Biomes, which remain largely unexplored. A new taxonomic key for the identification of males of the Brazilian species is provided.
\end{abstract}

Keywords. Endemism, Minas Gerais, Pará, Serra dos Carajás, temporary ponds.

Rabet N., Lacau S. \& Bozelli R.L. 2018. Richness of Dendrocephalus (Branchiopoda, Anostraca) in Brazil with the description of two new species. European Journal of Taxonomy 478: 1-20. https://doi.org/10.5852/ejt.2018.478 


\section{Introduction}

Fairy shrimps (Anostraca) represent an important component of the diversity of temporary freshwater pools, yet only three genera have been recorded in Brazil: Artemia Leach, 1819, Branchinecta Verril, 1869, and Dendrocephalus Daday, 1908 (Rabet \& Thiéry 1998). Until now, the genus Dendrocephalus has included 18 species split into two subgenera (Rogers 2006): three in the subgenus Dendrocephalinus Rogers, 2006 distributed in the USA (Rogers 2006) and 15 species in the subgenus Dendrocephalus Daday, 1908 with a Neotropical distribution. Six species have been described in Brazil, but several authors have suggested that many other species might be present (Chaves et al. 2011; Rogers \& Volcan 2016). Here, we synthesize the existing knowledge of the morphology and distribution of these different Brazilian species of Dendrocephalus and, thanks to new samples, we describe the seventh and eighth species from Brazil. We also review the intraspecific variability and discuss the taxonomic interest of some characters, as well as describing some details about the particular variability in Dendrocephalus carajaensis Rogers, Gomes \& Vieira, 2012.

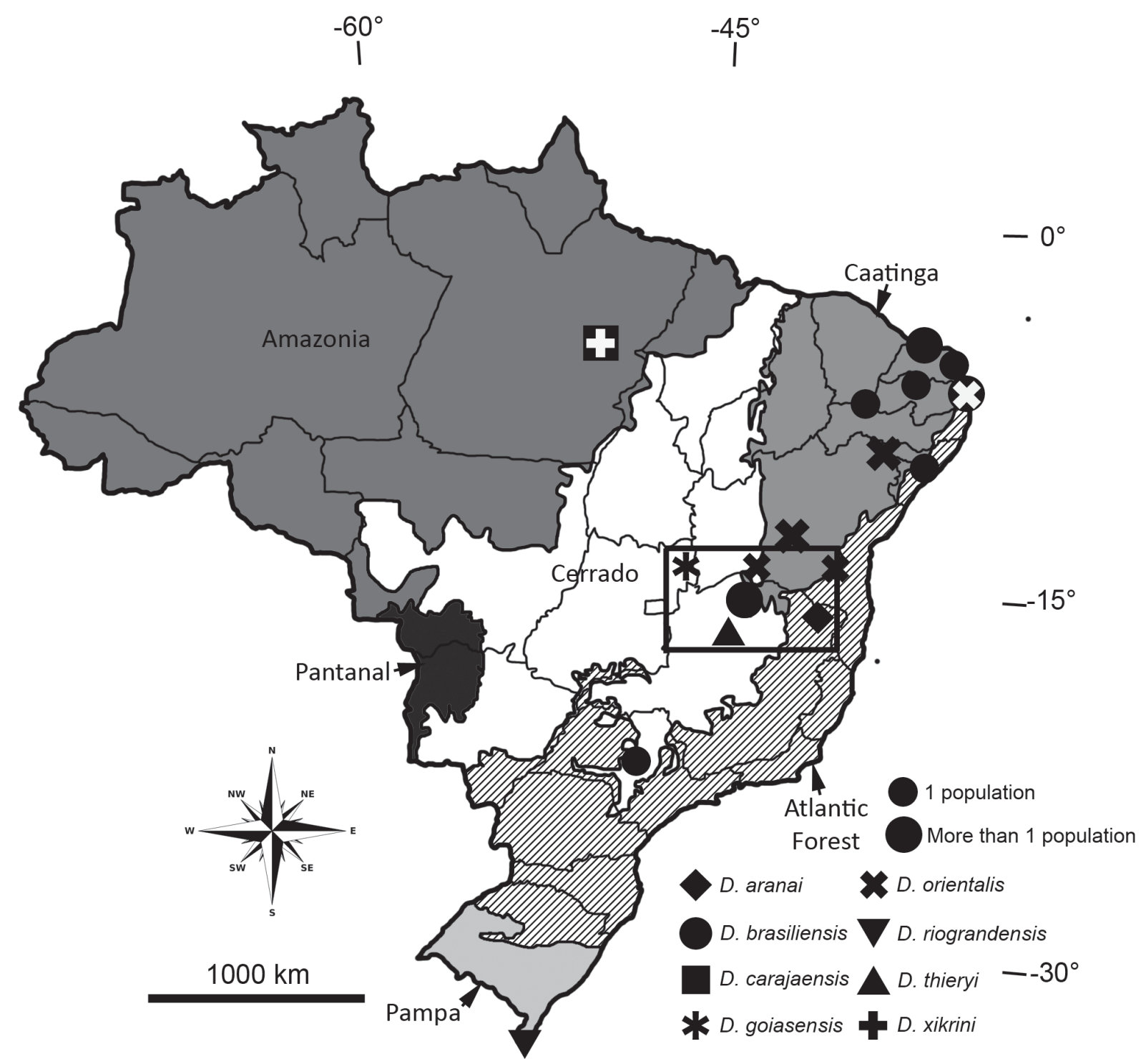

Fig. 1. Distribution of Brazilian Dendrocephalus Daday, 1908. The main biomes are indicated on the map, the empty black square delineates the hotspot of richness of Dendrocephalus in Brazil. The symbols are black except in the case of sympatry, where one of the species is in white. 


\title{
Material and methods
}

Specimens of Dendrocephalus were collected in two samples from different areas of Brazil. Their morphology revealed that they represent undescribed species: 15 specimens were collected by T. Chaves on 17 January 2009 in pool $\mathrm{n}^{\circ} 4$ in Jequitinhonha, Minas Gerais $\left(16^{\circ} 25^{\prime} 10.47^{\prime \prime} \mathrm{S}, 40^{\circ} 57^{\prime} 4.46^{\prime \prime} \mathrm{W}\right)$ and 12 specimens were collected by R. Bozelli on 25 November 2013 in pool S11-BC in Serra dos Carajás, Pará $\left(6^{\circ} 21^{\prime} 06.27^{\prime \prime} \mathrm{S}, 50^{\circ} 23^{\prime} 43.66^{\prime \prime} \mathrm{W}\right)$ (Figs 1, 7). These collections were stored in 70\% ethanol and the specimens from Serra dos Carajás were placed in glycerine to facilitate handling. Morphological illustrations were prepared using a compound microscope with a camera lucida and eggs were prepared for scanning electron microscopy (JEOL JSM 6100) following Felgenhauer (1987), except that postfixation in osmium was not performed.

The holotypes, the allotypes and several paratypes were deposited at the Museu Nacional de Rio de Janeiro, Rio de Janeiro, Brazil (MNRJ); additional paratypes of Dendrocephalus are deposited at the Muséum national d'Histoire naturelle, Paris, France (MNHN), remaining material collected for this study is held in the personal collections of the first and third authors, N. Rabet (coll. NR) and R.L. Bozelli. The total length of the specimens was measured from the anterior margin of the head to the apices of the cercopods including the setae, and cercopod length was measured from the telson to the apex of the distal setae. Egg diameter was estimated as the average of three measurements made during SEM observations. Descriptive terminology of the frontal appendage follows Pereira (1983).

Other studied specimens were identified following adapted literature (Pereira 1983, 1984; Pereira \& Belk 1987; Pereira \& Ruiz 1995; Rabet \& Thiéry 1996; Rabet 2006; Rogers et al. 2012; Hirose et al. 2015; Rogers \& Volcan 2016; Barros-Alves et al. 2016).

\section{Results}

All the known Brazilian populations of Dendrocephalus are geolocalized on the map of Brazil (Fig. 1).

\section{New and updated species}

\author{
Class Branchiopoda Latreille, 1817 \\ Order Anostraca Sars, 1867 \\ Family Thamnocephalidae Packard, 1877 \\ Genus Dendrocephalus Daday, 1908 \\ Subgenus Dendrocephalus (sensu stricto) Daday, 1908
}

Dendrocephalus aranai Rabet \& Lacau sp. nov. urn:Isid:zoobank.org:act:222FFFBE-BD26-4191-BC3E-A5D3864B07B4

Figs $1-3,7 \mathrm{H}$

\section{Etymology}

'Aranã' is the Portuguese (Brazil) name for an indigenous Brazilian tribe in the 'Vale do Jequitinhonha' region, which is near the type locality. Today, their population has been nearly extinguished, so the new species is named in honour of these people.

\section{Material examined}

Holotype

BRAZIL: mature $\hat{\delta}$, total length $24.1 \mathrm{~mm}$, cercopods $4.2 \mathrm{~mm}$, Minas Gerais, Jequitinhonha, $16^{\circ} 25^{\prime} 10.47^{\prime \prime} \mathrm{S}, 40^{\circ} 57^{\prime} 4.46^{\prime \prime} \mathrm{W}$, temporary pool no 4, 17 Jan. 2009, T. Chaves leg. (MNRJ 27970) (Fig. 7H). 
Allotype

BRAZIL: mature $q$, total length $21.7 \mathrm{~mm}$, brood pouch $5.5 \mathrm{~mm}$ reaching the $5^{\text {th }}$ abdominal segment, cercopods $4.1 \mathrm{~mm}$, same collecting data as for holotype (MNRJ 27971).

\section{Paratypes}

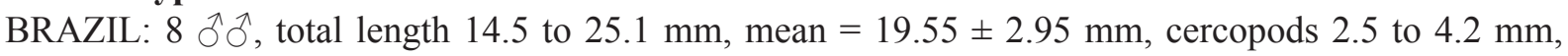
mean $=3.28 \pm 0.5 \mathrm{~mm}$, same collecting data as for holotype; 4 q , , total length 17 to $20.6 \mathrm{~mm}$, mean $=$ $18.33 \pm 1.58 \mathrm{~mm}$, brood pouch 4 to $4.7 \mathrm{~mm}$, mean $=4.43 \pm 0.31 \mathrm{~mm}$, cercopods 3.1 to $3.6 \mathrm{~mm}$, mean $=$ $3.25 \pm 0.31 \mathrm{~mm}$, same collecting data as for holotype ( $2 \hat{\jmath}, 2$ 우 0 in MNHN (MNHN-IU-2016-3558); $2 \widehat{\partial} \widehat{\jmath}, 1$ in MNRJ (MNRJ 27972)). Other specimens kept in NR's personal collection.

\section{Type locality}

The pool (Fig.7H) is in a well-lit location at a climatic crossroads with influences from the Atlantic Forest, Cerrado and lesser Caatinga. The other large branchiopods sampled in the same ponds are Eulimnadia colombiensis Roessler, 1989.

\section{Description}

\section{Male}

Eye pedunculate, ovoid in lateral view with a prominent spine. Length of the spine relative to the eye between 10 and 20\% (Fig. 2A). Antenna-like outgrowth slender, lying between first antennae and second antennae. Second antennae with proximal antennomeres fused basally on the anterior of the head. Proximal antennomere mediodistally bearing a stout digitiform process ornamented with setae. Distal antennomere weakly sclerotized, evenly curved medially, and ornamented on the medial surface with scaliform transverse ridges; terminus acute. Frontal appendages with anterior margin of the base of the arms with three or four spines (Fig. 2B). Arms from the base to the terminal branches with spines (Fig. 2B). Frontal appendage complex with one ventral branch (1V) and three terminal branches (2V, $2 \mathrm{D}, 2 \mathrm{~A})$. The terminal appendage in the medial position, called branch $2 \mathrm{~A}$, with a podiform apex and one long cell pad present proximally, parallel to the main axis, and a more lateral structure resembling a 'cell pad' on a bulge. A long spiniform process is present basally (Fig. 2C). A ventral branch called branch $1 \mathrm{~V}$ with two sub-branches. Sub-branch I (most proximal) with one row of spines on the medial side, a swollen extremity with five spines posteriorly oriented and three to five small cell pads anteriorly oriented. Branch $1 \mathrm{~V}$ distally ramified in two sub-branches, both with a longitudinal row of medial spines (Fig. 2D). Sub-branch II $3 / 4$ of the length of sub-branch I and with a row of short spines on the medial side with an acute extremity (Fig. 2D). Terminal and ventral branch called branch $2 \mathrm{~V}$ cylindrical and ending in a cluster of five to seven cell-pads on a bulge, with two rows of cell pads and a long cell pad on the medial surface (Fig. 2E). Terminal branch in the dorsal position called branch 2D is subdivided into three sub-branches. Sub-branch I (most proximal) with a row of short spines on the medial side and with three long spines (length more than four times the diameter of the sub-branch) (Fig. 3A). Sub-branch II shorter than half of sub-branch I with three long spines (gradually decreasing in size towards the apical part from three times the length to twice the length of the diameter of the sub-branch) (Fig. 3A). Subbranch III $3 / 4$ shorter and five times wider than sub-branch I, bearing two large spiniform processes, and with a distally flattened portion with two spines on the posterolateral side (Fig. 3A). Endopodite of the first pair of thoracopods with a basolateral lobe ending in one to four smooth spines and a distolateral non-prominent border with two spines (Fig. 3B). Endopodites of limb 2 with a prominent distolateral border ornamented with 12-13 spines and a strong, small extension with two small spines (Fig. 3C). Endopodites of limb 3 with a prominent distolateral border ornamented with 12-13 spines (Fig. 3D). Endopodites of limb 4 with only eight small spines on the distolateral corner (Fig. 3E). No differentiation was observed in the fourth limbs (Fig. 3E). Abdominal segments smooth. Cercopods margined with plumose setae. 


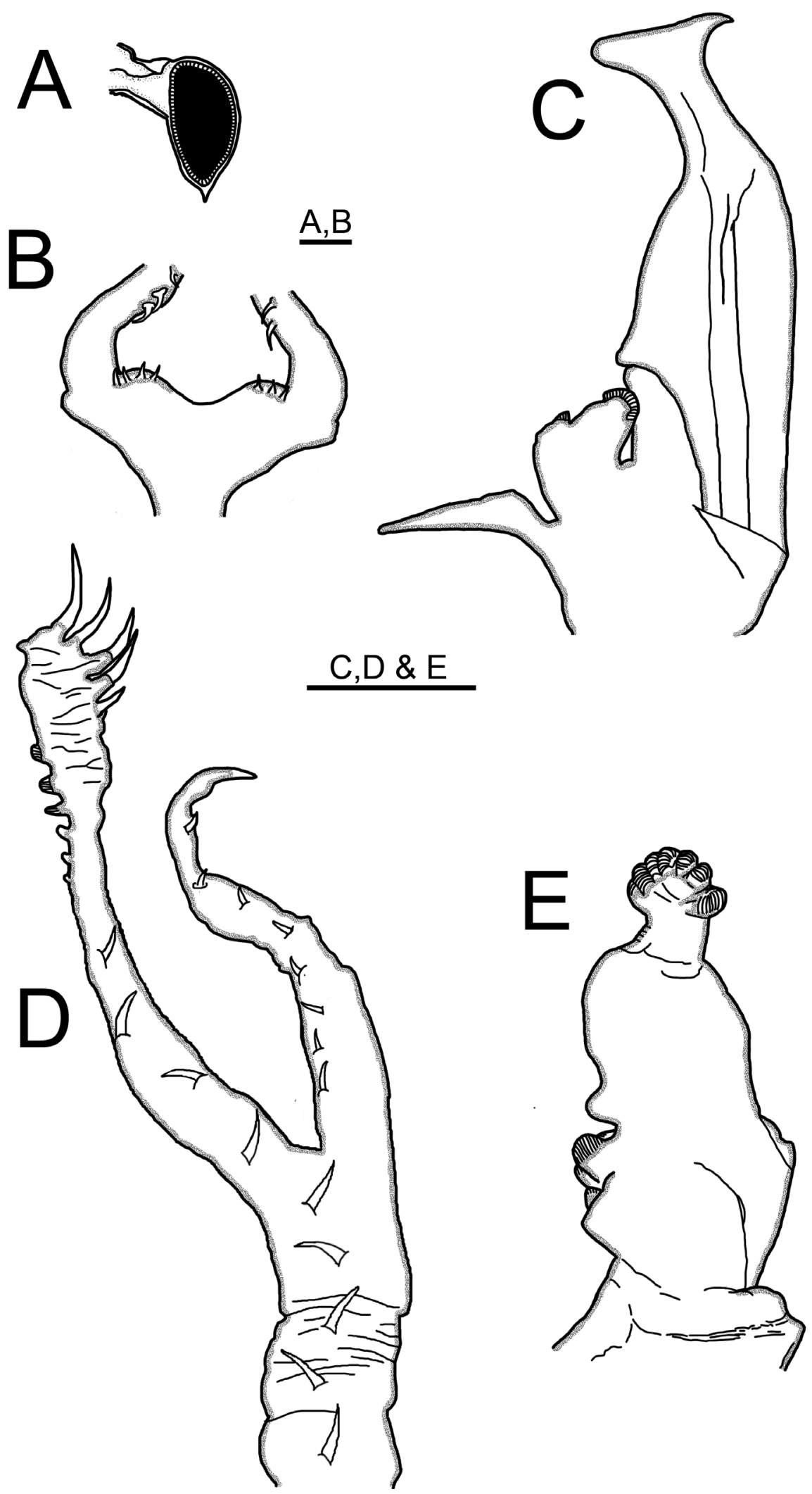

Fig. 2. Dendrocephalus aranai Rabet \& Lacau sp. nov., đ. A. Eye with a spine on the posterior edge. B. Basal part of the frontal appendage. C. Branch 2A of the frontal appendage. D. Branch 1V. E. Branch 2V. Scale bars: $1 \mathrm{~mm}$. 

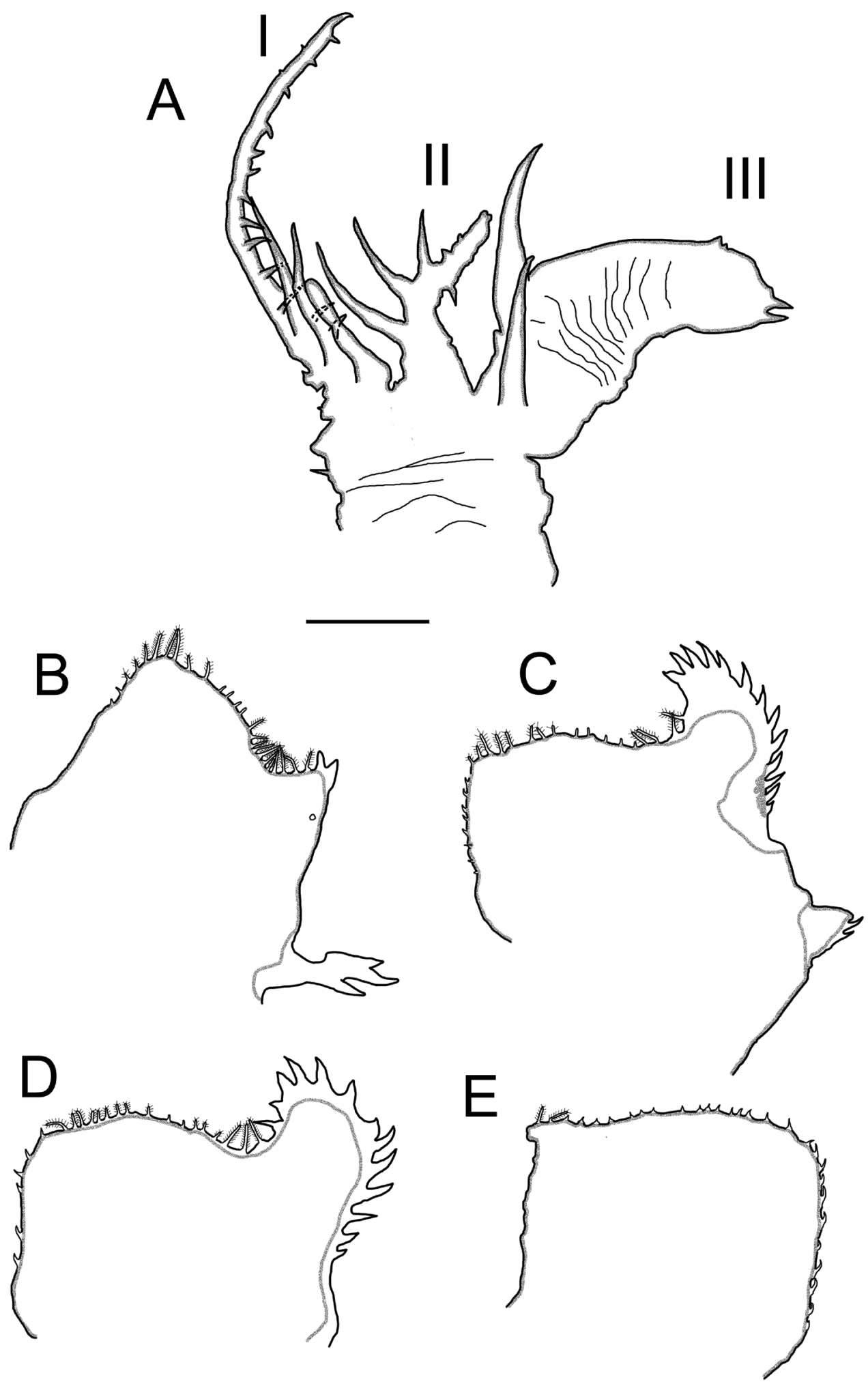

Fig. 3. Dendrocephalus aranai Rabet \& Lacau sp. nov., O. A. Branch $2 \mathrm{D}$ of the frontal appendage. B. Endopodite of the first limb. C. Endopodite of the second limb. D. Endopodite of the third limb. E. Endopodite of the fourth limb. Scale bar: $0.5 \mathrm{~mm}$. 


\section{Female}

Typical of the genus.

\section{Resting egg}

Subspherical with broad pentagonal or quadragonal facies. Diameter ranging from 222 to $247 \mathrm{~mm}$, mean $=236.1 \pm 7.79 \mathrm{~mm}(\mathrm{n}=8$, diameter based on three measurements for each egg $)$. Depression number ranging from 7 to 8 , mean $=7.88 \pm 0.35(n=8)$.

\section{Distribution}

This species is known from several pools in the area next to the locus typicus.

Dendrocephalus carajaensis Rogers, Gomes \& Vieira, 2012 Figs 4, 7B

\section{Material examined}

BRAZIL: 12 animals, Pará, Serra dos Carajás, pool N1-A, 20 Nov. 2011, R. Bozelli leg. (Reinaldo Bozelli personal collection); 12 animals, Pará, Serra dos Carajás, pool N1-C, 22 Oct. 2013, R. Bozelli leg. (Reinaldo Bozelli personal collection); 12 animals, Pará, Serra dos Carajás, pool N7, 23 Oct. 2013, R. Bozelli leg. (Reinaldo Bozelli personal collection); 12 animals, Pará, Serra dos Carajás, pool S11DC, 24 Nov. 2013, R. Bozelli leg. (Reinaldo Bozelli personal collection) (Fig. 7B).

\section{Description}

Similar to the original description (see Rogers et al. 2012) including the following variations: branch $2 \mathrm{~V}$ variable with one to three extremities, the tip of each with a cell pad. Branch $2 \mathrm{~A}$ with a basal spine of varying shape from sinuate to straight (Fig. 4A-B). One or two basal cell pads produced. Anterior end sometimes arcuate or straight but always acute apically (Fig. 4A-B). Sub-branch III of branch 2D with varying shape from monoramal to biramal with various intermediate states. In some cases, three or five spiniform projections present in the posterior face of the sub-branch (Fig. 4C-D). In some individuals, two projections can fuse to form an elongate projection with two acute extremities (Fig. 4E-F) or form an elongate ramus sharing spiniform projections as in the original description (see Rogers et al. 2012).

\section{Habitat}

The specimens studied in the present work were all collected in natural pools in an Amazonian savannah in the Serra dos Carajás (Canga deposits), see Fig. 7B.

Dendrocephalus xikrini Rabet \& Bozelli sp. nov. urn:1sid:zoobank.org:act:D01C2A1B-75C2-4297-B1D3-B8B2564EB672

Figs 1, 5-6, 7I

\section{Etymology}

Named in honour of the Xikrin, a subgroup of indigenous people from the Kayapó tribes living in the area of the Serra dos Carajás.

\section{Material examined}

\section{Holotype}

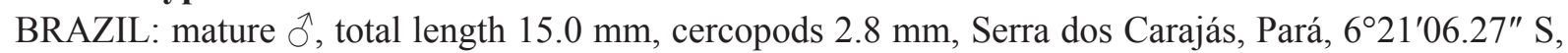
50²3'43.66" W, pool S11-BC in an Amazonian savannah (Canga deposits), 25 Nov. 2013, R. Bozelli 

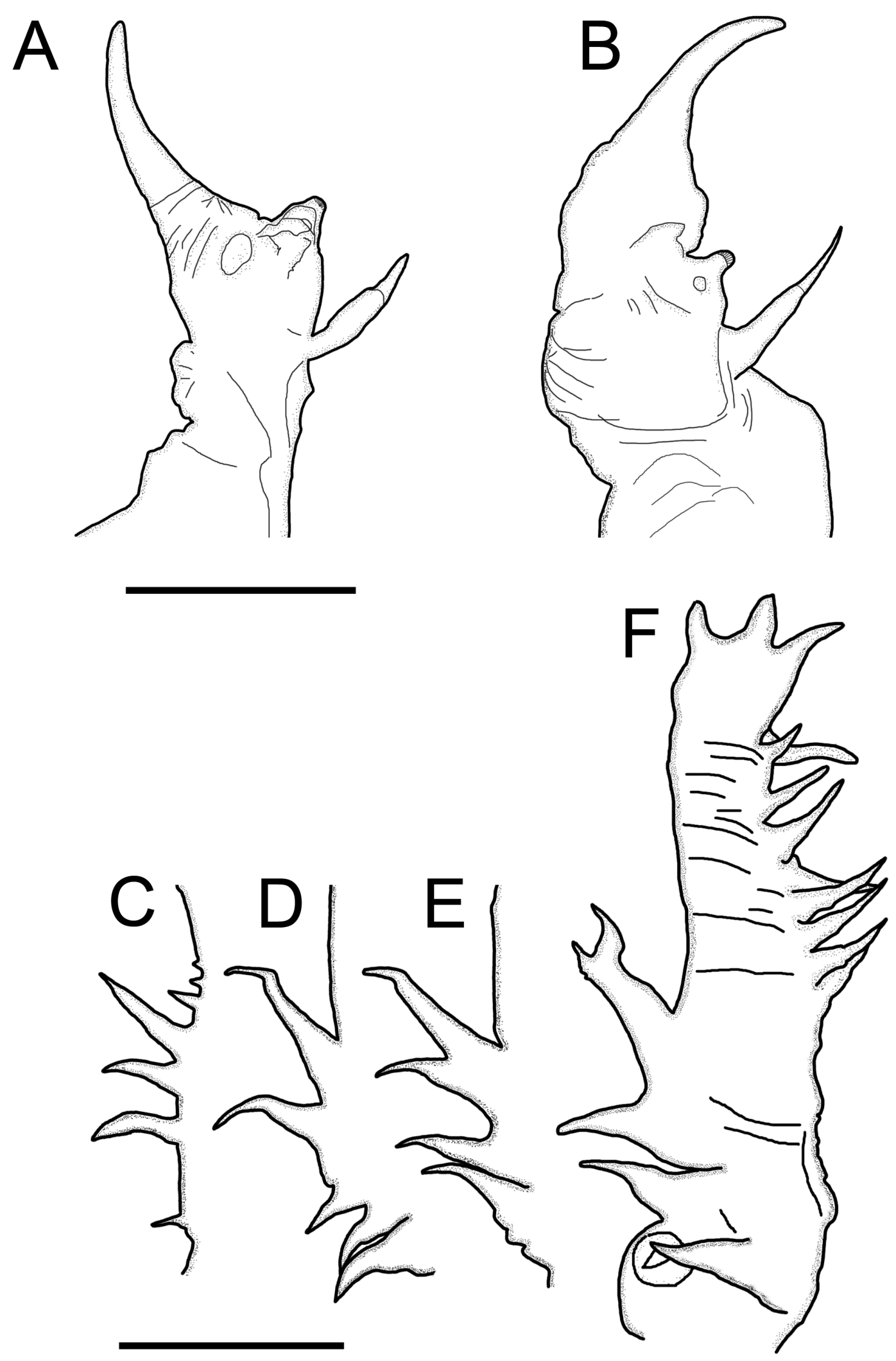

Fig. 4. Morphological variation in the frontal appendage of Dendrocephalus carajaensis Rogers, Gomes \& Vieira, 2012, Oे. A-B. Branch 2A from two specimens. C-F. Sub-branch III of branch 2D from different specimens. Scale bars: $0.5 \mathrm{~mm}$. 
leg. (MNRJ 2973). In the same study period, approximately 30 phytoplankton species, 30 zooplankton species and 15 aquatic macrophyte species were recorded in the pool, but no fish were observed.

\section{Allotype}

BRAZIL: mature $q$, total length $12.8 \mathrm{~mm}$, brood pouch $2.9 \mathrm{~mm}$ reaching the extremity of the $6^{\text {th }}$ abdominal segment (including genital segments), cercopods $2.7 \mathrm{~mm}$, same collecting data as for holotype (MNRJ 2974).

\section{Paratypes}

BRAZIL: $8 \hat{\partial}$, same collecting data as for holotype, total length 15.1 to $16.5 \mathrm{~mm}$, mean $=15.75 \pm$ $0.58 \mathrm{~mm}$, cercopods 2.3 to $2.7 \mathrm{~mm}$, mean $=2.56 \pm 0.15 \mathrm{~mm}$; 1 , same collecting data as for holotype, length $13.5 \mathrm{~mm}$, brood pouch $3 \mathrm{~mm}$, cercopods $3 \mathrm{~mm}$ ( $2 \widehat{\partial}$, 1 q $\mathrm{MNHN}$ (MNHN-IU-2016-3559); $2 \widehat{\partial} \widehat{\partial}$ in MNRJ (MNRJ 2975)). Other specimens are kept in personal collections of NR and RLB.

\section{Type locality (Figs 1, 7I)}

Pool S11-BC is the smallest (average area of $0.13 \mathrm{ha}$ ) among the previously studied lentic aquatic environments in the Serra dos Carajás inside the Carajás National Forest. Although very shallow (0.10 to $0.25 \mathrm{~m}$ ) during our sporadic explorations from 2005-2013, the pool was never found completely dry, and during this period, its volume ranged from 56 to $140 \mathrm{~m}^{3}$. Nevertheless, it is a temporary pool because it was possible to verify that the pool dried up in Google Earth images from August 2006. The electrical conductivity of the water varies between 4 and $64 \mu \mathrm{S} / \mathrm{cm}$ and $\mathrm{pH}$ varied between 4.89 and 5.63. The recorded turbidity values were between 1 and 64 NTU, but the water was always completely transparent.

\section{Description}

\section{Male}

Eye pedunculate, ovoid in lateral view with a prominent spine. Length of the spine relative to that of the eye between 10 and 20\% (Fig. 5A). Antenna-like outgrowth slender, lying between the first antennae and second antennae. Second antennae with proximal antennomeres fused basally on the anterior of the head. Proximal antennomere mediodistally bearing a stout digitiform process ornamented with setae. Distal antennomere weakly sclerotized, evenly curved medially, and ornamented on the medial surface with scaliform transverse ridges; terminus acute. Frontal appendages with anterior margin of the base of the arms with three or four spines (Fig. 5B). Arms from the base to the terminal branches with spines (Fig. 5B). Frontal appendage complex with one ventral branch (1V) and three terminal branches (2V, $2 \mathrm{D}$, and $2 \mathrm{~A}$ ). The terminal appendage in the medial position called branch $2 \mathrm{~A}$ with a podiform apex and one well-developed cell-pad on the first third of the branch. A long spiniform process is present basally (Fig. 5C). Ventral branch called branch $1 \mathrm{~V}$ with two sub-branches. Sub-branch I (most proximal) with one row of spines on the medial side with an acute extremity (Fig. 5D). Sub-branch II $3 / 4$ of the length of sub-branch I and with a row of short spines on the medial side with an acute extremity (Fig. 5D). Terminal ventral branch called branch $2 \mathrm{~V}$ cylindrical and ending in a cluster of four to five cell-pads on a bulge and four rows of cell pads on the medial surface (Fig. 5E). Terminal branch in the dorsal position called branch 2D subdivided into three sub-branches. Sub-branch I (most proximal) with a row of short spines on the medial side and with three or four long spines (length of which is more than twice the diameter of the sub-branch) in the first half of the sub-branch (Fig. 6A). Sub-branch II longer than half of sub-branch I, with a row of small spines on the medial side and with two long spines (the length of which is greater than or equal to the diameter of the sub-branch) in the first half and half the length of the sub-branch (Fig. 6A). Sub-branch III slightly shorter than sub-branch I (80\%) with twice the average diameter, proximally cylindrical and distally flattened and bearing a large spiniform process; distal flattened portion with two or three long spines (equalling the width of the sub-branch) on the posterolateral side (Fig. 6A). Endopodite of the first pair of limbs with a reduced basolateral lobe sharing 

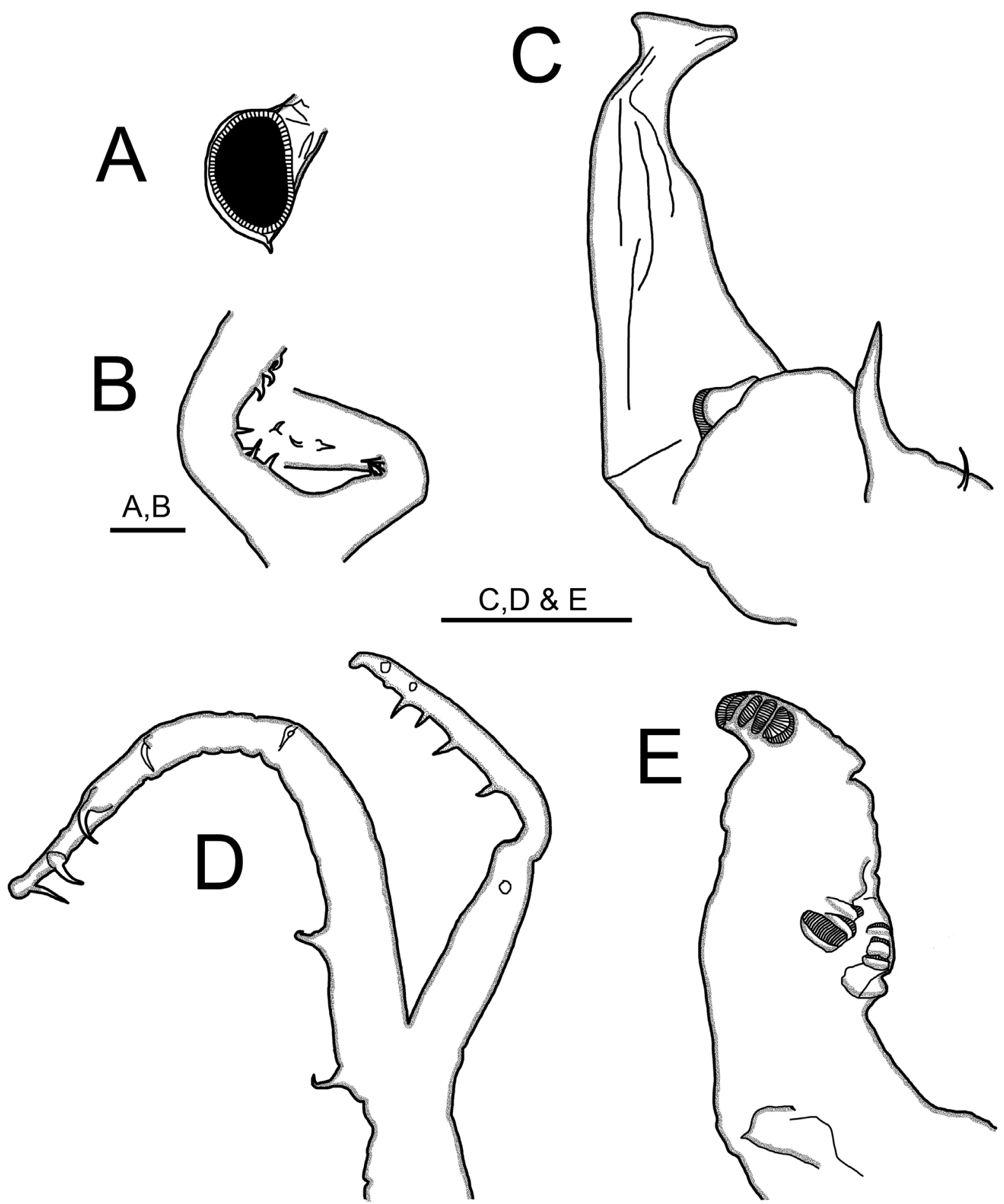

Fig. 5. Dendrocephalus xikrini Rabet \& Bozelli sp. nov., §ิ. A. Eye with a spine on the posterior edge. B. Basal part of the frontal appendage. C. Branch 2A of the frontal appendage. D. Branch 1V. E. Branch 2V. Scale bars: $1 \mathrm{~mm}$. 

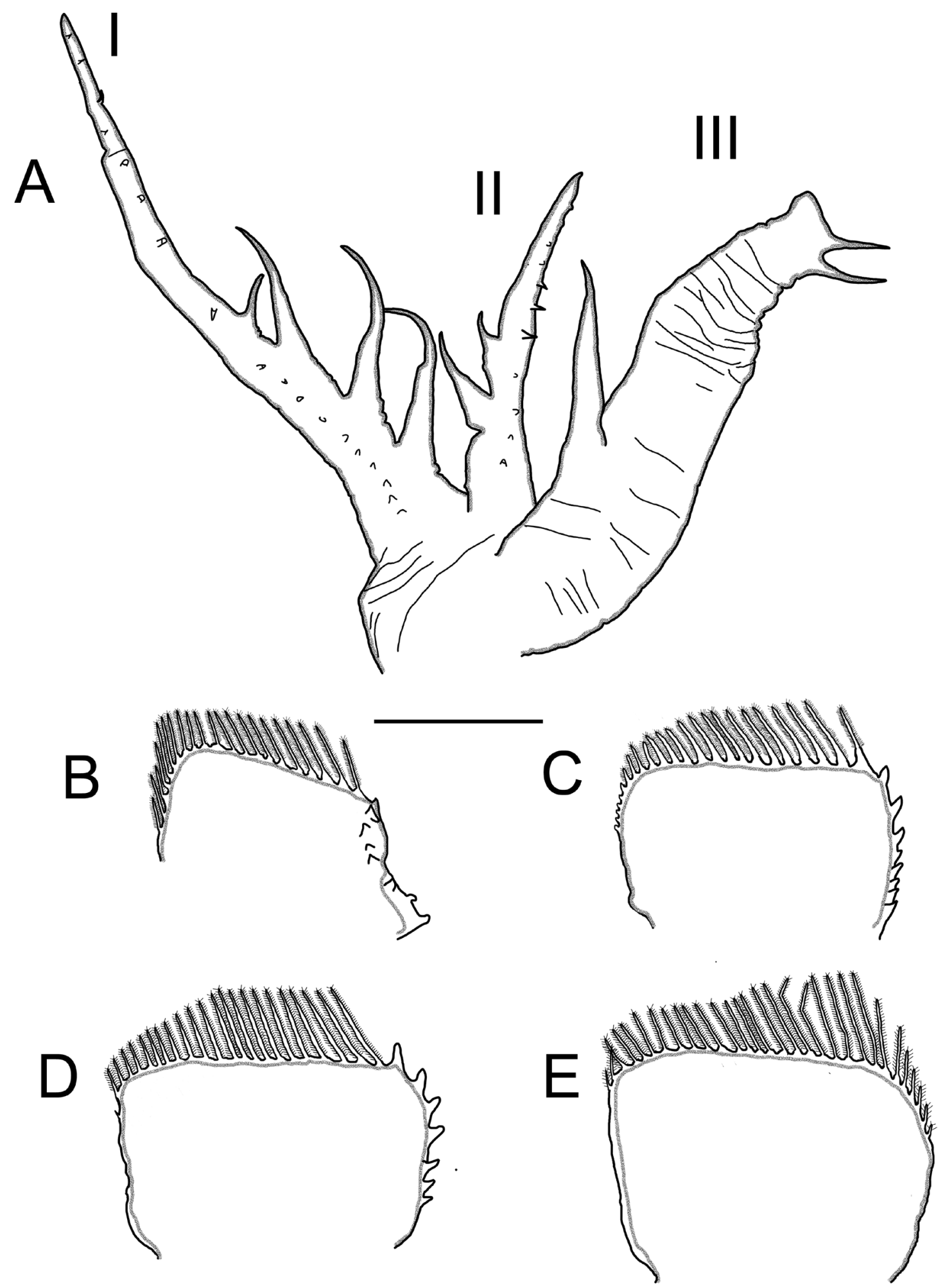

Fig. 6. Dendrocephalus xikrini Rabet \& Bozelli sp. nov., ô. A. Branch 2D of the frontal appendage. B. Endopodite of the first limb. C. Endopodite of the second limb. D. Endopodite of the third limb. E. Endopodite of the fourth limb. Scale bar: $0.5 \mathrm{~mm}$. 
small spines that form a row extending to the distal corner (Fig. 6B). Endopodite of the second pair of limbs with a border sharing large spines (Fig. 6C). Endopodite of the third pair of limbs similar to the second with slightly larger spines (Fig. 6D). No differentiation was observed in the fourth pair of limbs (Fig. 6E). Abdominal segments smooth. Cercopods margined with plumose setae.

\section{Female}

Typical of the genus.

\section{Resting egg}

Similar to those of $D$. aranai sp. nov., subspherical with broad pentagonal or quadragonal facies.

\section{Distribution}

Known only from the locus typicus. Other pools prospected in the Carajás Mountains are inhabited by D. carajaensis only.

\section{Other Brazilian species examined}

From the studied samples and the literature (Pesta 1921; Lutz 1929; Lemos de Castro \& Lima 1986; Rabet \& Thiéry 1996; Rabet 2006; Chaves et al. 2011; Rogers et al. 2012; Hirose et al. 2015; Rogers \& Volcan 2016; Barros-Alves et al. 2016), we analysed the morphological characters shared by the frontal appendage and the limbs of all Brazilian species of Dendrocephalus and summarized these observations in Tables 1-3. All the known locations of Dendrocephalus are indicated on the map of Brazil (Fig. 1).

Dendrocephalus brasiliensis Pesta, 1921

\section{Material examined}

BRAZIL: 10 animals, Rio Grande do Norte, Caicó, fish tank, 6 Aug. 1993, N. Rabet leg.; 2 animals, Rio Grande do Norte, Mossoró, ESAM, 27 Feb. 1980, Lemos de Castro and P. Coelho leg.; 10 animals, Paraíba, João Pessoa, temporary pools, 18 Jul. 1993, N. Rabet leg.; 2 animals, Minas Gerais, Januária, $15^{\circ} 05^{\prime} 03.3^{\prime \prime} \mathrm{S}, 4^{\circ} 05^{\prime} 21.4^{\prime \prime} \mathrm{W}$, temporary pool, 7 Feb. 1994, W. Costa, G. Brasil and C. Campinha leg.; 2 animals, Minas Gerais, Januária, temporary pool, 6 Feb. 2003, J. Goma Pinto and D. Pillet leg.; 4 animals, Ceará, Brejo Santo, Açude Atalhos, 6 Dec. 1998, U. Caramaschi, R.N. Feio and H. De Nieweyer leg. (MNRJ 15893) (Fig. 7A). All specimens kept in NR's personal collection.

Dendrocephalus goiasensis Rabet \& Thiéry, 1996

\section{Material examined}

BRAZIL: 4 paratypes, Goiás, Iaciara, temporary pool, 16 Jan. 1989, W. Costa and J. C. Oliveira leg.; 2 animals, Goiás, Iaciara, temporary pool, 2 Feb. 2003, J. Goma Pinto and D. Pillet leg. (Fig. 7C). All specimens kept in NR's personal collection.

\section{Dendrocephalus orientalis Rabet \& Thiéry, 1996}

\section{Material examined}

BRAZIL: 5 paratypes, Paraíba, João Pessoa, Cabo Branco, temporary pond, 21 Jul. 1993, N. Rabet leg.; 4 animals, Bahia, near Oliveira dos Brejinhos, temporary pond along the Caturama-Macaúbas and Boquira-Beira Rio roads, 25-26 Jan. 1994, P.S. Young and M.C. Britto-Pereira leg.; 4 animals, Bahia, Jequié, 23 Jan. 2002, S. Lacau leg. (Fig. 7D); 4 animals, Bahia, Palmas de Monte Alto, rock pool, 23 Dec. 2014, M.L. Oliveira, N.S. Silva, H. Gonçalves and J.G. Neto leg. (Fig. 7E). All specimens kept in NR's personal collection. 

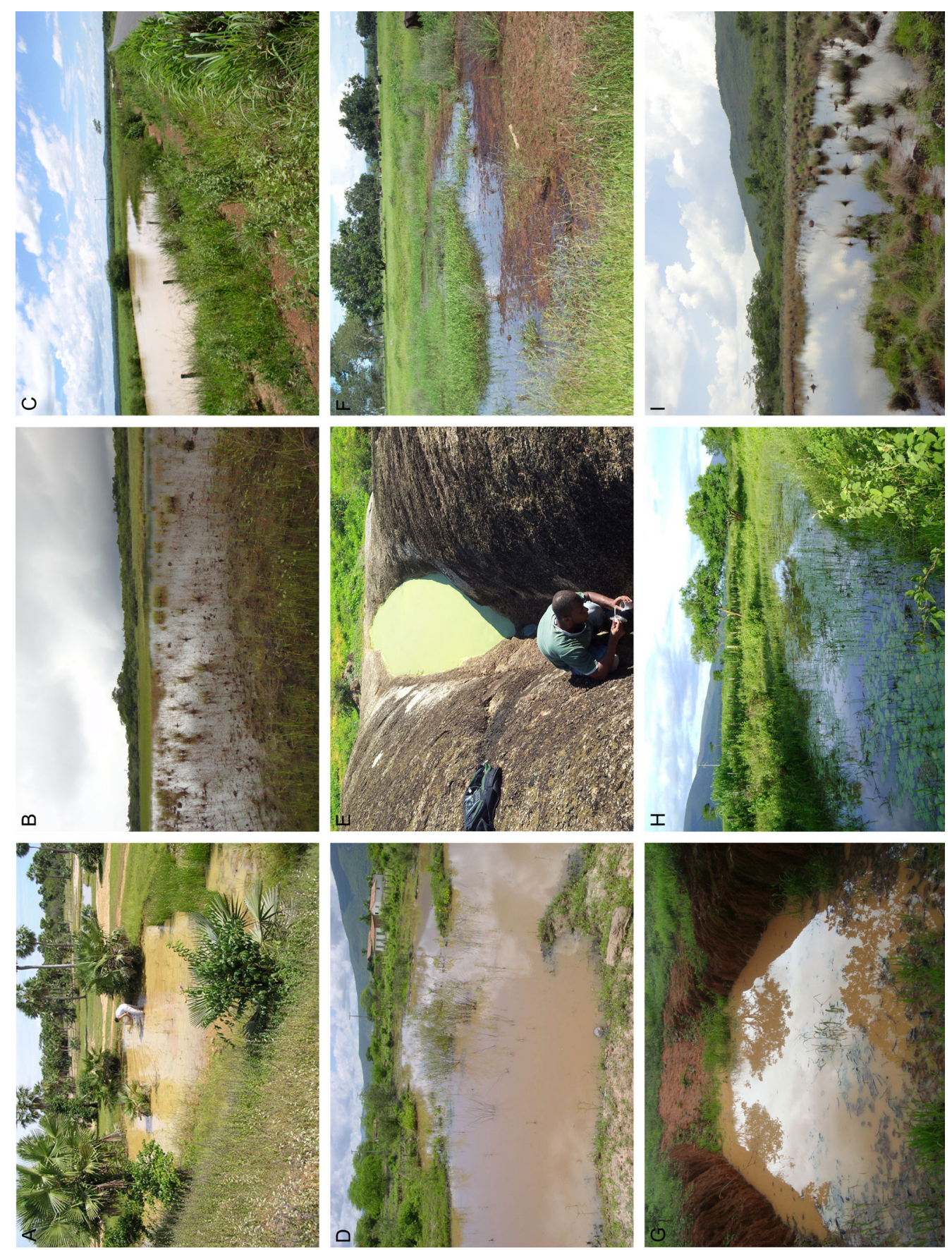

ত̄ :

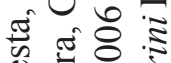

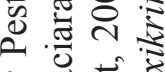

氙苛

छ छ त्ञ

है

ㅇำ

त

责

ठ

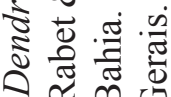

यं

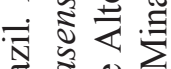

ติ

$\Xi \stackrel{\infty}{0} \overline{0}$
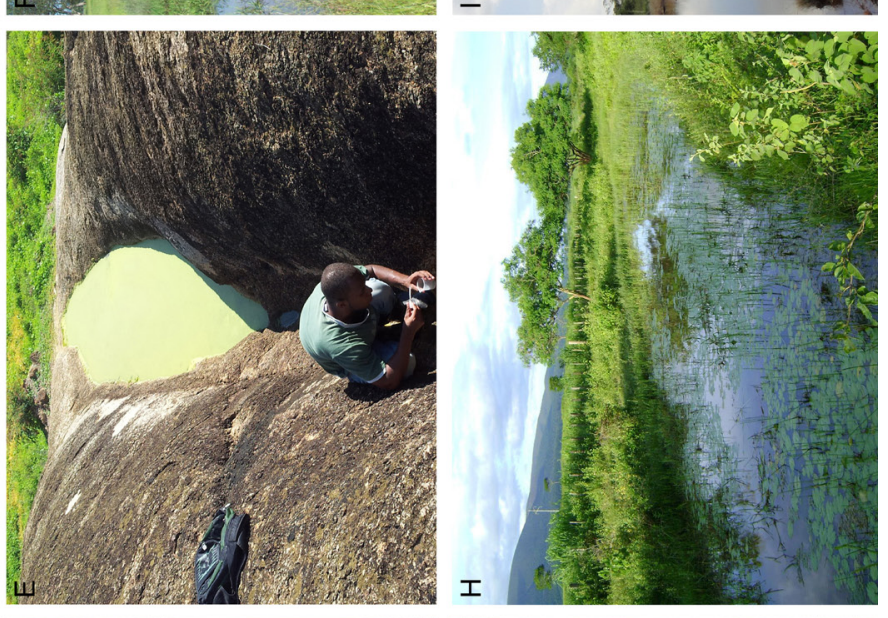

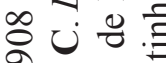

-

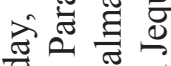

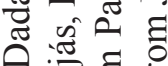

渮

胥

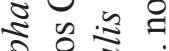

क्ष

氙

จ

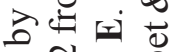

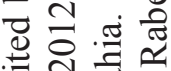
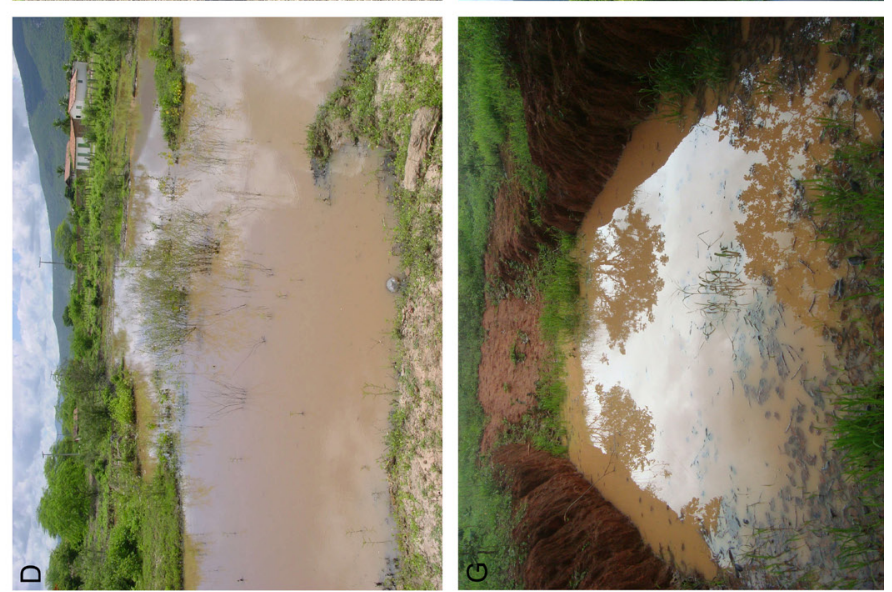

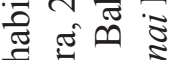

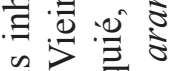

क छ

츔

की

छ

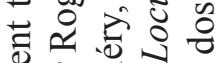

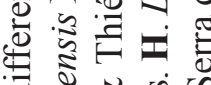

$\because \& \infty \dot{\theta} \backsim$

น

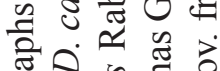

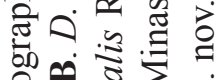
율 $\sum_{0}$

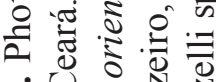
$\therefore \cup$

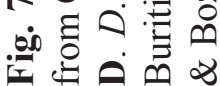


Table 1. Cephalic richness in Brazilian Dendrocephalus Daday, 1908. The bold characters correspond to characters allowing a direct determination of species in Brazil. Sub-branch II is indicated as short when it was less than half of sub-branch I.

\begin{tabular}{ccccccc}
\hline $\begin{array}{c}\text { Brazilian } \\
\text { species }\end{array}$ & Eye spines & $\begin{array}{c}\text { Spines on } \\
\text { Primary } \\
\text { branch }\end{array}$ & $\begin{array}{c}\text { Primary } \\
\text { branch from } \\
\text { base to termi- } \\
\text { nal branches } \\
\text { with spines }\end{array}$ & $\begin{array}{c}\text { Extremity of } \\
\text { Sub-branch I }\end{array}$ & Sub-branch II & $\begin{array}{c}\text { Shape of the } \\
\text { extremity of } \\
\text { branch 2A }\end{array}$ \\
\hline D. aranai & 1 & $3-4$ & Yes & Swollen & Long & podiform \\
D. brasiliensis & 0 & 0 & Yes & Swollen & Short & podiform \\
D. carajaensis & 0 & 0 & No & Swollen & Short & acute \\
D. goiasensis & 1 & $3-4$ & Yes & Acute & Long & podiform \\
D. orientalis & $\mathbf{2}(\mathbf{0 - 2})$ & $\mathbf{1}(\mathbf{0}-\mathbf{3})$ & Yes & Swollen & Long & unguiform \\
D. riograndensis & 1 & 3 & Yes & Acute & Short & podiform \\
D. thieryi & 1 & $3-4$ & Yes & Swollen & Long & podiform \\
D. xikrini & 1 & $3-4$ & Yes & Acute & Long & podiform \\
\hline
\end{tabular}

Dendrocephalus thieryi Rabet, 2006

\section{Material examined}

BRAZIL: 4 paratypes, Minas Gerais, Buritizeiro, temporary pond, 6 Feb. 1994, W. Costa, G. Campinha and G. Campelo leg.; 4 animals, Buritizeiro, pool 10, temporary pond, 5 Dec. 2008, L. Godinho leg. (Fig. 7F); 4 animals, Minas Gerais, Buritizeiro; pool 20, artificial temporary pond, 6 Dec. 2008, L. Godinho leg. (Fig. 7G). All specimens kept in NR's personal collection.

\section{Discussion}

\section{Habitat and distribution}

Species of Dendrocephalus inhabit temporary aquatic habitats in different climatic zones (see Figs 1, 7), particularly pools with variable types of sediment including granitic rock (Fig. 7E). Therefore, there are at least eight species of Dendrocephalus that live in tropical or subtropical areas in Brazil (this study), while Branchinecta, the sole other freshwater genus of Anostraca living in the country, is rather restricted to the subtropical zones of Southern Brazil (Lilljeborg 1889; Rabet \& Thiéry 1998) or at lower latitudes in the mountains of Minas Gerais (Rogers \& Ferreira, 2007).

Sympatry of species of Dendrocephalus does not appear to be widespread in Brazil and to date has been observed around João Pessoa, where $D$. orientalis and D. brasiliensis have even been found in the same pools (Rabet \& Thiéry 1996), as well as in the Serra dos Carajás, where D. carajaensis sp. nov. and D. xikrini sp. nov. live in the same area (this paper). However, in the latter case, the species have not yet been found in the same pool.

Distribution of Dendrocephalus reflects that Brazil has not yet been completely surveyed. Indeed, surveys for anostracans have still to be conducted in the Pantanal Biome or in a large part of the Cerrado and Amazonian savannah, which remain unexplored. It also appears that dense forest environments do not favour the fairy shrimps, which would explain their rarity in the east which has traditionally been more intensively studied. Fairy shrimps seem to have only been collected in forest margins or highland areas of savannah, such as in the Serra dos Carajás, or in environments influenced influenced more by seasonal dry climates, such as in the Northern Atlantic Forest (João Pessoa) or the interior of Minas Gerais (Jequitinhonha). 
Table 2. Richness in Brazilian Dendrocephalus Daday, 1908. The bold characters correspond to characters allowing a direct determination of species in Brazil.

\begin{tabular}{|c|c|c|c|c|c|c|}
\hline \multirow{2}{*}{$\begin{array}{c}\text { Brazilian } \\
\text { species }\end{array}$} & \multirow{2}{*}{$\begin{array}{c}\text { Extremity } 2 \mathrm{~V} \\
\begin{array}{c}\text { Number of } \\
\text { cell pads }\end{array}\end{array}$} & \multicolumn{5}{|c|}{ Branch 2D } \\
\hline & & $\begin{array}{c}\text { Long spines } \\
\text { at base of sub- } \\
\text { branch I }\end{array}$ & $\begin{array}{c}\text { Relative } \\
\text { length of sub- } \\
\text { branch II vs } \\
\text { sub-branch I }\end{array}$ & $\begin{array}{l}\text { Long spines } \\
\text { at base of sub- } \\
\text { branch II }\end{array}$ & $\begin{array}{l}\text { Shape of the } \\
\text { extremity of } \\
\text { sub-branch } \\
\text { III }\end{array}$ & $\begin{array}{l}\text { Long spines } \\
\text { at base of sub- } \\
\text { branch III }\end{array}$ \\
\hline D. aranai & $>4$ & 2 & More than $1 / 2$ & 3 & $\begin{array}{l}\text { Thick and flat } \\
\text { with } 2 \text { terminal } \\
\text { small spines }\end{array}$ & 2 \\
\hline D. brasiliensis & $>4$ & 3 & Less than $1 / 2$ & 0 & $\begin{array}{l}\text { Thick and flat, } \\
\text { small spines } \\
\text { in internal and } \\
\text { external part }\end{array}$ & 1 \\
\hline D. carajaensis & $1-3$ & 0 & Very reduced & 0 & $\begin{array}{l}\text { Thick and flat } \\
\text { with many } \\
\text { small spines in } \\
\text { external part }\end{array}$ & 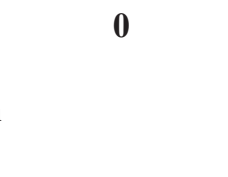 \\
\hline D. goiasensis & $>4$ & 3 & More than $1 / 2$ & 4 & $\begin{array}{c}\text { Thick and flat } \\
\text { with } 3 \text { external } \\
\text { spines }\end{array}$ & 2 \\
\hline D. orientalis & $>4$ & 0 & More than $1 / 2$ & 0 & Cylindrical & 2 \\
\hline D. riograndensis & 2 & 4 & More than $1 / 2$ & 2 & $\begin{array}{l}\text { Apex asymme- } \\
\text { trical, sub- } \\
\text { truncate }\end{array}$ & . \\
\hline D. thieryi & $>4$ & 0 & More or less $1 / 2$ & 更 & $\begin{array}{l}\text { Thick and flat } \\
\text { with external } \\
\text { and some inter- } \\
\text { nal small spines }\end{array}$ & . \\
\hline D. xikrini & $>4$ & 3 & More than $1 / 2$ & 2 & $\begin{array}{l}\text { Thick and flat } \\
\text { with } 2 \text { external } \\
\text { long spines }\end{array}$ & 1 \\
\hline
\end{tabular}

\section{Hotspot richness}

The distribution of Dendrocephalus also indicates that there is a hotspot of Anostraca richness in the climate interface between the Cerrado, Caatinga and the Atlantic Forest. Indeed, we have listed five species in an area of approx. $400 \times 800 \mathrm{~km}$ that includes Iaciara, Jequié, Palmas de Monte Alto and Buritizeiro (approximately $400 \mathrm{~km}$ by $800 \mathrm{~km}$ ), which means that more than $60 \%$ of the known species for Brazil can be found in less than $4 \%$ of the surface area of the country (Fig. 1).

Another interesting point is the importance of rugged terrain culminating in isolated ferruginous rock plateaux, called Canga, in the diversification of fairy shrimps. Indeed, the discovery of $D$. xikrini sp. nov. brings the total number of fairy shrimps present on this type of substrate in Brazil to three; Branchinecta 
Table 3. Endopodite richness in Brazilian Dendrocephalus Daday, 1908. The bold characters correspond to characters allowing a direct determination of species in Brazil.

\begin{tabular}{|c|c|c|c|c|c|c|}
\hline \multirow[t]{2}{*}{ Brazilian species } & \multicolumn{2}{|c|}{$1^{\text {st }}$ endopodite } & \multicolumn{2}{|c|}{$2^{\text {nd }}$ endopodite } & \multicolumn{2}{|c|}{$3^{\text {rd }}$ endopodite } \\
\hline & $\begin{array}{l}\text { Exterior } \\
\text { proximal } \\
\text { corner }\end{array}$ & $\begin{array}{c}\text { Exterior distal } \\
\text { corner }\end{array}$ & $\begin{array}{l}\text { Exterior proxi- } \\
\text { mal corner }\end{array}$ & $\begin{array}{c}\text { Exterior distal } \\
\text { corner }\end{array}$ & $\begin{array}{c}\text { Exterior proxi- } \\
\text { mal corner }\end{array}$ & $\begin{array}{c}\text { Exterior distal } \\
\text { corner }\end{array}$ \\
\hline D. aranai & $\begin{array}{l}\text { Expansion lon- } \\
\text { ger than wide, } \\
\text { ending with a } \\
\text { few spines }\end{array}$ & $\begin{array}{l}\text { Small spiny } \\
\text { lobe }\end{array}$ & $\begin{array}{l}\text { Expansion shor- } \\
\text { ter than wide, } \\
\text { ending with a } \\
\text { few short spines }\end{array}$ & $\begin{array}{l}\text { Pronounced } \\
\text { spiny lobe }\end{array}$ & No expansion & $\begin{array}{l}\text { Pronounced } \\
\text { spiny lobe }\end{array}$ \\
\hline D. brasiliensis & No expansion & Spiny border & No expansion & Spiny border & No expansion & Spiny border \\
\hline D. carajaensis & No expansion & $\begin{array}{l}\text { Small spiny } \\
\text { lobe }\end{array}$ & No expansion & $\begin{array}{l}\text { Pronounced } \\
\text { spiny lobe }\end{array}$ & No expansion & Small spiny lobe \\
\hline D. goiasensis & $\begin{array}{l}\text { Expansion lon- } \\
\text { ger than wide, } \\
\text { ending with a } \\
\text { few spines }\end{array}$ & $\begin{array}{l}\text { Small spiny } \\
\text { lobe }\end{array}$ & No expansion & $\begin{array}{l}\text { Small spiny } \\
\text { lobe }\end{array}$ & No expansion & $\begin{array}{l}\text { Pronounced } \\
\text { spiny lobe }\end{array}$ \\
\hline D. orientalis & $\begin{array}{l}\text { Expansion lon- } \\
\text { ger than wide, } \\
\text { ending with a } \\
\text { few spines }\end{array}$ & Spiny border & No expansion & Spiny border & No expansion & Spiny border \\
\hline D. riograndensis & $\begin{array}{l}\text { Spiniform } \\
\text { expansion }\end{array}$ & $\begin{array}{l}\text { Pronounced } \\
\text { spiny lobe }\end{array}$ & No expansion & $\begin{array}{l}\text { No differencia- } \\
\text { tion }\end{array}$ & No expansion & $\begin{array}{l}\text { No differencia- } \\
\text { tion }\end{array}$ \\
\hline D. thieryi & $\begin{array}{l}\text { Expansion lon- } \\
\text { ger than wide, } \\
\text { ending with a } \\
\text { few spines }\end{array}$ & $\begin{array}{l}\text { Small spiny } \\
\text { lobe }\end{array}$ & $\begin{array}{l}\text { Spiniform } \\
\text { expansion }\end{array}$ & $\begin{array}{l}\text { Pronounced } \\
\text { spiny lobe }\end{array}$ & No expansion & $\begin{array}{l}\text { Pronounced } \\
\text { spiny lobe }\end{array}$ \\
\hline D. xikrini & $\begin{array}{l}\text { Expansion } \\
\text { shorter than } \\
\text { wide }\end{array}$ & Spiny border & No expansion & Spiny border & No expansion & Spiny border \\
\hline
\end{tabular}

ferrolimneta Rogers \& Ferreira, 2007 was discovered in Minas Gerais (Rogers \& Ferreira 2007) and D. carajaensis was also collected in Serra dos Carajás (Rogers et al. 2012). This type of temporary pool is particularly interesting, especially because mining activities in these areas threaten these highly vulnerable species with habitat destruction (Rogers \& Ferreira 2007; Rogers et al. 2012).

\section{Differential diagnosis}

The two new species described here bear an eye spine, three or four spines at the base of the frontal appendage primary branches, a podiform extremity on branch $2 \mathrm{~A}$ and a relatively massive sub-branch III of branch 2D, which is similar to D. cornosuris Pereira \& Ruiz, 1995, D. cornutus Pereira \& Belk, 1987, D. spartanovae Margalef, 1961 and the Brazilian species D. goiasensis Rabet \& Thiéry, 1996, D. thieryi Rabet, 2006 and D. riograndensis Rogers \& Volcan, 2016. Essentially, the differences between these species are therefore in the shapes of branch $1 \mathrm{~V}$, branch $2 \mathrm{D}$ and the limbs; D. cornosuris, D. cornutus, $D$. spartanovae and $D$. riograndensis have a smooth and acute spiniform expansion at the base of the endopodite of limb I whereas $D$. aranai sp. nov. and $D$. xikrini sp. nov. have a basal expansion with small spines. The two new species are relatively similar, but they can be easily separated by the shape of the extremity of branch $1 \mathrm{~V}$, which is acute in D. xikrini sp. nov. and swollen in D. aranai sp. nov., as well as by the shape of the limbs. The endopodites of limb I in D. xikrini sp. nov. have a short basal expansion, 
whereas those in D. aranai sp. nov. have a long basal expansion. Additionally, the endopodites of limb II and III in D. aranai sp. nov. have a spinous lobe that is absent in D. xikrini sp. nov. D. aranai sp. nov. and $D$. goiasensis have similar limbs and 2D branches, but differ in the end of branch $1 \mathrm{~V}$ which is acute in $D$. goiasensis but swollen in $D$. aranai $\mathrm{sp}$. nov. D. aranai sp. nov. is also very similar to $D$. thieryi, with which it was compared in the key by Chaves et al. (2011), notably at the level of branch $1 \mathrm{~V}$. However, $D$. thieryi is very different due to the absence of long spines at the base of the endopodites of sub-branches I and II of branch 2D, which also distinguishes it from D. xikrini sp. nov. Finally, D. xikrini sp. nov. is also different from $D$. goiasensis in the shape of its limbs. Indeed, the expansion of the limb I endopodite is short in D. xikrini sp. nov., but long in D. goiasensis. The spinous lobe on the endopodites of limb II and III of D. goiasensis are also absent in D. xikrini sp. nov.

\section{Variability and difficulty of identification}

Recently, Hirose et al. (2015) reported variable characters of the eye and the base of the branches in D. orientalis. In D. carajaensis, we found variations in branch $2 \mathrm{~A}$, branch $2 \mathrm{~V}$ and sub-branch III of branch 2D within a population across several populations (Fig. 4). However, we have not found such variations in other species, so we believe that this species may have a greater morphological variability than others. This demonstrates that a population approach is needed for the delineation of species of Dendrocephalus.

The morphological richness within Dendrocephalus requires a combination of diagnostic characters rather than a single discriminating trait. Many of these characters are present in several taxa, but only a particular combination is species specific. Nevertheless, some of the salient characters given in Tables 1-3 could be sufficient to directly identify Brazilian species, but in most cases they are present in other species outside of Brazil. For example, in Brazil only the frontal appendage of D. carajaensis possesses primary branches without spines from the base to the terminal branches, but this character is present in other species, particularly in D. cervicornis (Weltner, 1890) (Weltner 1890; Daday 1910; Pereira 1983). The unguiform extremity of branch 2A is only present in D. orientalis in Brazil, but it is also found in D. venezolanus Pereira, 1984 and D. argentinus Pereira \& Belk, 1987. The spiniform expansion in the endopodite I described in D. riograndensis in Brazil is also found in D. cornutus, D. cornosuris, D. spartanovae and D. venezolanus (Margalef 1961; Pereira 1984; Pereira \& Belk 1987; Pereira \& Ruiz 1995), while the spiniform expansion in the endopodite II described in D. thieryi is also present in D. venezolanus or D. cornutus (Pereira 1984; Pereira \& Belk 1987). Similarly, the acute shape of the extremity of branch $2 \mathrm{~A}$ in $D$. carajaensis is unique in Brazil but found elsewhere, such as in D. cervicornis or D. sarmentosus (Pereira 1983; Pereira \& Belk 1987).

However, some of these characters are quite significant and are not present in other species, such as the presence of a single spine at the base of the frontal appendage primary branches or the presence of two eye spines that are only reported in the Brazilian species $D$. orientalis. Unfortunately, the use of this trait is problematic, as it has been shown to be particularly variable (Hirose et al. 2015).

The branch 2D seems to be taxonomically interesting because it has a large number of points of variation that can be used as diagnostic in combination, but a precise, comparative study of multiple populations is necessary. Thus far, only D. carajaensis has such a reduced sub-branch II.

In the future, we believe that genetic studies will be very useful in better delineating species of Dendrocephalus, especially widely distributed species such as D. brasiliensis (see Barros-Alves et al. 2016), to detect possible cryptic species as well as to better understand the diversification of species with restricted distributions, such as $D$. aranai sp. nov. or D. xikrini sp. nov. We also believe that collection efforts should be intensified in the Pantanal, in the Amazonian savannah and in the Cerrado, where it is likely that new species will be discovered in the future. 


\section{Key for all known species of Brazilian Dendrocephalus}

A key based on male characters is presented for all known species of the Brazilian Dendrocephalus, and we recommend verifying the coherence of the determination with Tables 1-3.

1. Proximal anterior surface of frontal appendage primary branches without spines .......................... 2

- Proximal anterior surface of frontal appendage primary branches with at least one spine ............... 3

2. Primary branches of frontal appendage with spines on medial surface, thoracopod I with endopodite without expansion

D. brasiliensis Pesta, 1921

- Primary branches of frontal appendage without spines, thoracopod I with endopodite with spiny expansion D. carajaensis Rogers, Gomes \& Vieira, 2012

3. Proximal anterior surface of frontal appendage primary branches generally with one spine and branch 2A extremity with a strongly sclerotized hook D. orientalis Rabet \& Thiéry, 1996

- Proximal anterior surface of frontal appendage primary branches with three to four spines and branch 2A extremity podiform

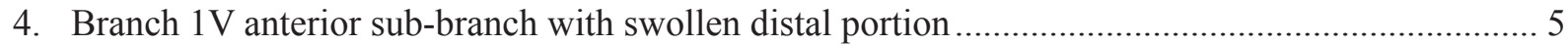

- Branch $1 \mathrm{~V}$ anterior sub-branch with acute distal portion.

5. Branch 2D, sub-branch I and II with several long spines............. D. aranai Rabet \& Lacau sp. nov.

- Branch 2D, sub-branch I and II without long spines. D. thieryi Rabet, 2006

6. Thoracopod III with endopodite producing distolateral corner

D. goiasensis Rabet \& Thiéry, 1996

- Thoracopod III with endopodite not producing distolateral corner.. 7

7. Thoracopod I with endopodite with basolateral spiniform projection; thoracopods II and III with endopod without large spines

D. riograndensis Rogers \& Volcan, 2016

- Thoracopod I with endopodite with small basolateral extension with spines; thoracopods II and III with endopod with large marginal spines

D. xikrini Rabet \& Bozelli sp. nov.

\section{Acknowledgements}

Special thanks to Túlio Paiva Chaves, Leandro Braga Godinho and Didier Pillet for providing photos and collecting specimens of Dendrocephalus in the field and making this work possible. We also acknowledge the staff of the Laboratório de Biossistemática Animal (UESB, Brazil) for help and photographs, and particularly Muriel Lima de Oliveira, Natália de Souza Silva, Herick Gonçalves, José Guilherme de Almeida Neto. We also thank David Montero for his help at the scanning electronic microscope, the Company VALE for financial support during the sampling in Serra dos Carajás and the Instituto Chico Mendes de Conservação da Biodiversidade (ICMBio) for providing the license for sampling (SISBIO 33647-2) and especially the staff of the Floresta Nacional de Carajás. RLB thanks the colleagues from the Laboratório de Limnologia for helping in the field and the Conselho Nacional de Desenvolvimento Científico e Tecnológico (CNPq) for providing a research grant (Proc. 306105/2014-4).

\section{References}

Barros-Alves S.P., Alves D.F.R., Bolla E.A. jr, Rabet N. \& Hirose G.L. 2016. Morphological review of the fresh water fairy shrimp Dendrocephalus brasiliensis Pesta, 1921 (Anostraca: Thamnocephalidae). Nauplius 24: z2016008. https://doi.org/10.1590/2358-2936e2016008 
Chaves T.P., Lacau S. \& Rabet N. 2011. Illustrated key to the Brazilian Dendrocephalus (Crustacea: Anostraca: Thamnocephalidae). Nauplius 19: 1-5. https://doi.org/10.1590/S0104-64972011000100001

Daday de Deés E. 1910. Monographie systématique des phyllopodes anostracés. Annales des Sciences naturelles, Zoologie Series 9: 91-489.

Felgenhauer B.E. 1987. Techniques for preparing crustaceans for scanning electron microscopy. Journal of Crustacean Biology 7: 71-76. https://doi.org/10.1163/193724087X00054

Hirose G.L., Barros-Alves S.P., Alves D.F.R., Silva I.R.S. \& Bezerra M.A.O. 2015. Morphological variation in males of Dendrocephalus orientalis (Anostraca: Thamnocephalidae): implications for species identification. Zootaxa 3915: 569-580. https://doi.org/10.11646/zootaxa.3915.4.7

Lemos-de-Castro A. \& Lima I.M.B. 1986. Sobre um crustáceo anostráceo reencontrado no estado do Rio Grande do Norte, Brasil (Crustacea, Branchiopoda). Anais do VII Congresso Brasileiro de Zoologia, Publicações Avulsas do Museu Nacional 66: 43-54.

Lilljeborg W. von. 1889. Diagnosen zweier Phyllopoden-Arten aus Süd-Brasilien. Abhandlungen des naturwissenschaftlichen Vereins zu Bremen 10: 424.

Lutz A. 1929. Dous phyllopodos, observados no Rio Grande do Norte. Instituto Oswaldo Cruz, Memorias del Rio de Janeiro, Supplemento 5: 3-9. https://doi.org/10.1590/S0074-02761929000200001

Margalef R. 1961. La vida en los charcos de agua dulce de Nueva Esparta (Venezuela). Memoria de la Sociedad de Ciencias Naturales La Salle 21: 75-110.

Pereira G. 1983. Taxonomic importance of the frontal appendage in the genus Dendrocephalus (Anostraca: Thamnocephalidae). Journal of Crustacean Biology 3: 293-305. https://doi.org/10.2307/1548264

Pereira G. 1984. Two new species of Dendrocephalus (Anostraca: Thamnocephalidae) from Venezuela. Journal of Crustacean Biology 4: 147-153. https://doi.org/10.2307/1547903

Pereira G. \& Belk D. 1987. Three new species of Dendrocephalus (Anostraca: Thamnocephalidae) from Central and South America. Journal of Crustacean Biology 7: 572-580. https://doi.org/10.2307/1548305

Pereira G. \& Ruiz L. 1995. A new species of Dendrocephalus (Anostraca, Thamnocephalidae) from Argentina. Crustaceana 68: 567-574. https://doi.org/10.1163/156854095X00818

Pesta O. 1921. Kritische Revision der Branchipodidensammlung des Wiener Naturhistorischen Staatsmuseum. Annalen des Naturhistorischen Museums in Wien 34: 80-98.

Rabet N. 2006. A new species of Brazilian Dendrocephalus (Anostraca, Thamnocephalidae). Zootaxa 1370: 49-57.

Rabet N. \& Thiéry A. 1996. The neotropical genus Dendrocephalus (Crustacea: Anostraca: Thamnocephalidae) in Brazil (South America), with a description of two new species. Journal of Natural History 30: 479-503. https://doi.org/10.1080/00222939600770261

Rabet N. \& Thiéry A. 1998. Branchiopoda. Anostraca and Spinicaudata: 3-10. In: Young P.S. (ed.) Catalogue of Crustacea of Brazil, $1^{\text {st }}$ edition. Museu Nacional, Brazil.

Rogers C. 2006. A genus level revision of the Thamnocephalidae (Crustacea; Branchiopoda; Anostraca). Zootaxa 1260: 1-25.

Rogers D.C. \& Ferreira A. 2007. A new species of Branchinecta (Crustacea: Anostraca) from Brasil. Zootaxa 1445: 27-34.

Rogers D.C. \& Volcan M.V. 2016. A new Dendrocephalus (Crustacea, Anostraca, Thamnocephalidae) from Rio Grande do Sul State, Brazil. Nauplius 24: e2016014.

https://doi.org/10.1590/2358-2936e2016014 
Rogers D.C., Corrêa-Gomes J.P. \& Vieira F. 2012. A new species of Dendrocephalus (Crustacea, Anostraca) from Serra dos Carajás (Pará State, Brasil). Zootaxa 3363: 52-58.

Weltner W. 1890. Branchipus (Chirocephalus) cervicornis, n. sp. aus Südamerika. Sitzungberichte der Gesellschaft Naturforschender Freunde zu Berlin 3: 35-41.

Manuscript received: 12 April 2018

Manuscript accepted: 25 July 2018

Published on: 22 November 2018

Topic editor: Rudy Jocqué

Desk editor: Kristiaan Hoedemakers

Printed versions of all papers are also deposited in the libraries of the institutes that are members of the EJT consortium: Muséum national d'Histoire naturelle, Paris, France; Botanic Garden Meise, Belgium; Royal Museum for Central Africa, Tervuren, Belgium; Natural History Museum, London, United Kingdom; Royal Belgian Institute of Natural Sciences, Brussels, Belgium; Natural History Museum of Denmark, Copenhagen, Denmark; Naturalis Biodiversity Center, Leiden, the Netherlands; Museo Nacional de Ciencias Naturales-CSIC, Madrid, Spain; Real Jardín Botánico de Madrid CSIC, Spain; Zoological Research Museum Alexander Koenig, Bonn, Germany. 